Bruce W. Menning

University of Kansas, Lawrence

bmenning@aol.com

https://doi.org/10.18485/ai_godine_ww1.2019.ch3

94(470)"1914/1918"

\title{
ADDITIONAL REFLECTIONS ON JULY 1914, OR THREE VARIATIONS ON THE THEME OF RUSSIAN MILITARY INTELLIGENCE
}

Summary: Several years ago I wrote an article on the role of Russian military intelligence during the July Crisis of 1914. ${ }^{1}$ For reasons of space I did not include an interesting sidelight on the part that intelligence-informed media played in the crisis. In addition, over the course of research since the appearance of the article, I uncovered materials that reveal several other important crisis-related insights. The first is testimony from a reliable source about an early assertion of tsarist resolve in support of Serbia, while the second is the degree to which unfolding reality either challenged or affirmed intelligence-driven perceptions of Austro-Hungarian troop mobilization and strategic deployments. The following remarks focus briefly on these three issues to bring additional Russian-oriented perspective to bear on the momentous events leading to the outbreak of the Great War.

\section{The Intelligence-Informed Point of Departure}

In the wake of significant failures during the Russo-Japanese War of 1904-05, the Russians revamped their military intelligence establishment to recruit competent personnel,

1 Bruce Menning, "Russian Military Intelligence, July 1914: What St. Petersburg Perceived and Why It Mattered," The Historian, LXXVII, no. 2, 213-68. 
allocate additional resources, and put in place improved procedures and structures. These changes bore fruit between 1909 and 1913, when the new emphasis on systematic collection, analysis, and dissemination of intelligence-related materials produced significant attainments. These came especially with regard to identification of warnings and indicators of war imminence that might emanate from Austria-Hungary. Germany figured in the larger picture, but only modestly so, since successes against Berlin were largely confined to conclusions of local and tactical significance. In contrast, well-placed sources in Austria-Hungary, including energetic military attachés, a certain Agent No. 25, and several espionage rings, generated a wealth of materials, including specific information on Austro-Hungarian strategic deployments against Russia and Serbia in the event of possible European war. ${ }^{2}$ The mobilization crisis of late 1912 during the First Balkan War afforded still more insight into the nature of Austro-Hungarian troop mobilization regimes, including the distinct possibility for hidden mobilization before any formal declaration of "Alarm" that might signal a pre-mobilization period. As materials and insights accumulated, military intelligence specialists and organs came to serve the vital role of institutional memory that linked the crisis of late 1912 with the July Crisis of $1914 .{ }^{3}$

Intelligence-informed memory highlighted several important conclusions from post-1912 analysis. The first was that any future partial Austro-Hungarian mobilization

2 Brius U. Menning, "Nasledie agenta No 25," Rodina, no. 8 (August 2014), 32-4.

3 Bruce W. Menning, "The Mobilization Crises of 1912 and 1914 in Russian Perspective: Overlooked and Neglected Linkages," in Andreas Gestrich and Hartmut Pogge von Strandmann, eds., Bid For World Power? New Research on the Outbreak of the First World War (Oxford: Oxford University Press, 2017), 230-31, and 235-36. 
would likely be accompanied by the covert mobilization of the three corps (I, X, and XII) resident in Galicia opposite the southern border of Russian Poland. This stark possibility confronted Russian war planners with pre-emption of their initial strategic deployments for war against Austria-Hungary. The second major conclusion was that in the event of a general European war Vienna would allocate six (possibly seven) corps against Serbia, leaving 8-10 for deployment against Russia. Should a future crisis initially remain confined to Serbia alone, any number of corps brought to war readiness in excess of six or seven would signify over-mobilization, with large strategic implications for Russia. The third major conclusion was the grave threat inherent in an assumed Austro-Hungarian preference to seek a quick coup de main against Serbia, followed by rapid troop transfers to Galicia (where the three resident corps would already have been mobilized and reinforced) for a regrouping of superior forces to confront Russia. These conclusions underscored the importance of the time-distance-mass calculus for Russia. They also confronted Russia with a Schlieffen-like dilemma opposite the border with Galicia: The entire Russian war plan was in jeopardy should rapidly deploying and advancing Austro-Hungarian troops win the race for possession of the Liublin-Kholm-Kovel' (Polish Lublin-Chełm-Kowel) rail corridor across the southern expanse of Russian Poland. The corridor itself was the east-west line of departure for initial Russian offensive operations into western Galicia. Although the corridor's single-track railroad was of minimal strategic importance, the three towns along the corridor constituted railheads for important Russian troop transit feeder lines from the north. If the corridor were lost to the invaders, then Russian dispositions for initial operations against Austria-Hungary would have to be withdrawn into the interior. Meanwhile, 
any substantial Austro-Hungarian incursion from Galicia would also threaten the rear areas of the two Russian armies attacking farther north into East Prussia. ${ }^{4}$

Emperor Nicholas II on the Likelihood of War, 12/25 July 1914

An often-overlooked development in the centennial-informed historiography of Russia's Great War is the outpouring of newly-published diaries and memoirs. Military memoirs especially, from War Minister Vladimir Aleksandrovich Sukhomlinov's reminiscences to General Anton Ivanovich Denikin's recollections, have figured prominently over the last century in various treatments of wartime and revolutionary Russia. ${ }^{5}$ They were sometimes published and annotated by early Soviet historians. ${ }^{6}$ But more often first-hand accounts were published abroad, in places as remote from each other as Helsinki and Buenos Aires. ${ }^{7}$ In

4 Bruce W. Menning, "The Russian Threat Calculation, 1910-1914," in Dominik Geppert, William Mulligan, and Andreas Rose, eds., The Wars before the Great War: Conflict and International Politics before the Outbreak of the First World War (Cambridge: Cambridge University Press, 2015), 171-2. A corps was an infantry-heavy combined arms formation, numbering more than 35,000 troops. Two to four corps under a unified command comprised a field army.

5 V. A. Sukhomlinov, Vospominaniia (Berlin: Russkoe universal'noe izdatel'stvo, 1924), and A. I. Denikin, Ocherki russkoi smuty, 5 vols. in 6 bks. (Paris and Berlin: J. Povolozky, and "Slovo," 1921-1926).

6 For example, A. A. Polivanov, Iz dnevnikov $i$ vospominanii po dolzhnosti voennogo ministra i ego pomoshchika, 1907-1916 g., ed. A. M. Zaionchkovskii (Moscow: Vysshii voennyi redaktsionnyi sovet, 1924).

7 For example, V. N. Voeikov, S tsarem i bez tsaria (Helsinki: Oy. Littera, 1936), and Iu. Makarov, Moia sluzhba v Staroi Gvardii (Buenos Aires: no publisher, 1951. 
contrast, the latest wave of memoirs and diaries frequently comes from the Russian archives, either where they have moldered since the 1920s or where they had lain inaccessible since 1945, the product of wartime Soviet booty from Russian emigré documentary repositories in East Europe. ${ }^{8}$ To a lesser extent, various materials also come from the descendants of emigrés, who after 1991 returned their forebears' papers to research institutions in the Russian Motherland. ${ }^{9}$ No matter the source and publication date, the breadth and depth of various memoirs are remarkable, and the new can be profitably perused along with the old.

Notable among the new wave of memoirs is Mikhail Ilarievich Pestrzhetskii's account of the initial period of the Great War from the perspective of a regimental commander. ${ }^{10}$ He begins with a brief history of his unit, the $12^{\text {th }}$ Astrakhan Grenadiers, of which Emperor Nicholas II since 1900 had borne the title of ceremonial commander/ patron (shef). During the summer of 1914, this distinction required the regiment to participate in the annual summer encampment and maneuvers outside St. Petersburg at Krasnoe Selo. They transpired in part during the outset of the July Crisis. It was during Nicholas II's formal review of the regiment at Krasnoe Selo that there occurred an important exchange between the Emperor and Colonel Pestrzhetskii about tsarist resolution and war imminence. However, the

8 For example, E. V. Ekk, Ot Russko-turetskoi do Mirovoi voiny: Vospominaniia o sluzhbe. 1868-1918 (Moscow: Kuchkovo pole, 2014, and A. E. Snesarev, Dnevnik: 1916-1917, ed. T. N. Mantsevich (Moscow: Kuchkovo pole, 2014.

9 For example, M. V. Alekseev, “Zapisnaia knizhka 1917-1918 gg. [11. 1-87]," ed. L. F. Pavlikovova, Zapiski otdela rukopisei, vyp. 53 (Moscow: Pashkov Dom, 2008), 298-432.

10 M. I. Pestrzhetskii, Vospominaniia komandira 12-go grenaderskogo Astrakhanskogo imperatora Aleksandra III polka (Moscow: Dom russkogo zarubezh'ia imeni Aleksandra Solzhenitsyna, 2011). 
value of the memoir extends beyond a significant exchange of remarks. Pestrzhetskii goes on to describe the scope and span of troop mobilization procedures. ${ }^{11}$ His description is significant because it affords a first-hand narrative of the mobilization timeline that challenges the veracity of some contemporaries and later historians who have equated the Russian declaration of The Period Preparatory to War with "secret mobilization." 12 The Astrakhan Grenadiers were normally headquartered in the Moscow Military District, and at the outset of war the regiment was to be transited to the frontier with Galicia to take part in initial offensive operations along the Liublin-Kholm-Kovel' rail corridor as part of General Adjutant Pavel Adamovich Pleve's Fifth Russian Army. Because of the immense distance between peacetime deployment and the locale of anticipated initial operations, speed was of the essence during assembly, transit, concentration, and movement to contact. Therefore, under conditions of a secret mobilization the Astrakhan Grenadiers would have been among the first to mobilize. Yet, Pestrzhetskii records no more than a normal mobilization regime within the regiment. Finally, Pestrzhetskii's memoir is important because he provides a first-hand account of the initial blood bath at the Galician frontier, followed by exploitation and pursuit to the Vistula and on to Kraków. Along the way, shortages of arms, ammunition, and rations testified to the multiple weaknesses inherent in Russian preparation for future European war.

With the ultimatum phase of the July Crisis not two days old, on Saturday morning, 12/25 July 1914, Emper-

11 Ibid., 45-50.

12 Early on, Gunther Frantz, Russlands Eintritt in den Weltkrieg (Berlin: Deutsche Verlagsgesellschaft für Politik und Geschichte, 1924), 62-3, and recently, Sean McMeekin, July 1914: Countdown to War (New York: Basic Books, 2013), 192-4, 207-9, and 214-15. 
or Nicholas II began his mounted review of the Astrakhan Grenadiers at precisely 0900 hours. Some minutes later, as he approached the regiment's third battalion, he beckoned Colonel Pestrzhetskii more closely to his side to impart a confidence. It was at this moment that the Emperor said, "You and your regiment evidently must hurriedly return to Moscow." In response to Pestrzhetskii's inquiring look, the Emperor added, "Yes, mobilization is foreseen, and if they [the Austrians] really do not make concessions, there will be war." ${ }^{13}$ The Emperor then ordered Pestrzhetskii to meet subsequently during a formal breakfast for the regiment's officers with War Minister Sukhomlinov to determine the unit's exact time of departure for Moscow. Unknown to Pestrzhetskii, the Emperor was meeting that same day between 1100 and 1200 hours in a crown session of his Council of Ministers, attended also by Grand Duke Nicholas Nikolaevich and the Chief of the Russian General Staff. The sole item on the agenda pertained to the nature of precautionary measures to be taken in light of the Austro-Hungarian ultimatum to Serbia, due to expire at 1800 hours that day. The Emperor's decision was to implement (with minor alteration) the measures proposed the previous day in a preliminary session of the Council of Ministers. Two of the more important of these measures included declaration of The Period Preparatory to War, beginning at midnight, and, should the situation require, approval in principle of partial troop mobilization within four of the eight military districts within European Russia. ${ }^{14}$

13 Pestrzhetskii, Vospominaniia, 36.

14 See the summary, Ronald P. Bobroff, "War Accepted but Unsought: Russia’s Growing Militancy and the July Crisis, 1914," in Jack S. Levy and John A. Vasquez, eds., The Outbreak of the First World War: Structure, Politics, and Decision-Making (Cambridge: Cambridge University Press, 2014), 243-44. 
Perhaps because of the necessity to await Vienna's official reaction to Belgrade's formal response to the ultimatum, Colonel Pestrzhetskii did not receive instructions from Sukhomlinov to entrain the Astrakhan Grenadiers for Moscow until about 0200 hours on 13/26 July. Later that day, after hurriedly departing St. Petersburg, Pestrzhetskii would find General Adjutant Pleve-oblivious of possible impending mobilization-calmly reviewing routine military exercises at Khodynka Field outside Moscow. ${ }^{15}$ Because The Period Preparatory to War did not entail secret mobilization, Pestrzhetskii's regiment did not begin formal mobilization until 18/31 July. The grenadiers would subsequently suffer heavy casualties during the frontier battles of 13/24-14/25 August 1914, in part because Russian military intelligence-despite all its pre-war attainments-failed to ascertain in advance the direction of the Austro-Hungarian main blow against Liublin on the extreme right flank of Russian dispositions along the Liublin-Kholm-Kovel' rail corridor. Pestrzhetskii's memoir thus provides important insight into the military-technical side of Russian troop mobilization and initial operations.

Just as important, his account injects the exactitude of a general staff officer's notes into a rare moment of tsarist candor over the possibility of war. Whether impending Russian mobilization would be partial or general, it was clear that Emperor Nicholas II displayed uncharacteristic resolve about Russia's likely course of action. There was no talk of Germany (indeed, German military attachés were still in attendance at the Krasnoe Selo maneuvers). Rumors at court abounded about the possibility of war, but Pestrzhetskii's subsequent audience with Empress Alexandra revealed that the Emperor had not yet shared his convictions with her.

15 Pestrzhetskii, Vospominaniia, 43. 
The majority of first-hand observations about the Emperor during the July Crisis either describe his outward demeanor or paraphrase his remarks. Pestrzhetskii was among the few who actually quoted the Emperor verbatim, and for this reason the memoir stands out. Finally, the Emperor's remarks also raise the question of the precise impact and importance of later intelligence-based perceptions of Austro-Hungarian war-readiness. If the Russian Emperor had already decided upon his course of action, then warning and readiness indicators may have simply confirmed his decision, rather than informing and determining it.

Media as Warning and Preparation:

The Case of Birzhevye vedomosti

Whatever role that various sources and perceptions played in Nicholas II's early decision-making, there is evidence to indicate that during the July Crisis military intelligence figured in an indirect attempt to serve notice on Vienna that Russia was well aware-should war come-of Austro-Hungarian capabilities, intentions, and objectives. In addition, the same attempt might explain to educated segments of the Russian public the rationale for tsarist posturing on the international scene. On two successive days, $14 / 27$ and 15/28 July, articles by a K. Shumskii appeared in the evening edition of Birzhevye vedomosti, a respected commercial-oriented daily that sometimes gave voice to prominent governmental officials. For example, much earlier in the year, during the so-called "newspaper war," War Minister Sukhomlinov had on 27 February/12 March published a provocative article, "Russia Wants Peace, But 
is Ready for War."16 Shumskii was the nom de plume for the paper's military correspondent, retired Lieutenant Colonel Konstantin Markovich Solomonov. After October 1915, he would continue to serve in the same capacity as resident correspondent for Birzhevye vedomosti at the wartime Headquarters (Stavka) of the Supreme Commander. In July 1914, his two articles were of such a technical nature that it is doubtful they could have been composed without the assistance of insight from sources based on Russian military intelligence.

In the first article, "Ha Galitsiiskom teatre [In the Galician Theater]," 14/27 July, Solomonov describes Austro-Hungarian peacetime deployments in Galicia, including extensive coverage on that province's three resident corps, I, X, and XI. ${ }^{17}$ He presumes that in the event of war Vienna would allocate at least four of its southern-most corps against Serbia, with the probability of two additional from the interior for reinforcement. This calculus would leave no more than 10-12 from a total of 16 for deployment against Russia. The requirement to counter other possible threats (Italy and Romania) would diminish the number available for action against Russia to 10 or fewer. Railroad throughput capacities to Galicia meant that five corps might reinforce the three already in place within a few days' time. Only the necessity to call up reservists on a territorial basis might slow the entire process. Thus far, Solomonov has confined his speculation to an enumeration of capabilities and locales, without discussing probable Austro-Hungarian courses of action.

In his second article, "Avstriiskaia 'pobeda' nad Rossiei. Zavoevanie 'Velikogo Kniazhestva Kievskogo [Austri-

16 Oleg Airapetov, Vneshniaia politika Rossiiskoi imperii (1801-1914) (Moscow: Izdatel'stvo “Evropa” 2006), 587.

17 Birzhevye vedomosti, no. 14250, 14 July 1914 (evening edition), 4. 
an "Victory" over Russia. The Conquest of the "Kievan Grand Princedom"]," 15/28 July, Solomonov builds on the previous day's article to delineate strategic objectives and military means. ${ }^{18}$ On the basis of a strategic war game allegedly held earlier in 1914 under the auspices of the late Austrian Grand Duke, Solomonov anticipates combined Austro-German offensive operations along two major avenues of advance into Russian territory. In accordance with this scenario, only four Austro-Hungarian corps would be left to confront Serbia and other possible adversaries in the south, thus liberating at least eleven Austro-Hungarian corps for offensive operations from Galicia. With the assistance of three German corps from Silesia, four Austro-Hungarian corps would be press north along one avenue through Liublin on to Siedlce. Following additional German reinforcement from East Prussia, the combined Austro-German advance would bear eastward to seize the Russian fortress at Brest-Litovsk.

Solomonov outlines a second major avenue of advance into Russian territory from eastern Galicia with a purely Austro-Hungarian force or seven corps. They were to attack through Russian concentrations at Rovno-DubnoProskurov with Kiev as the final objective. On the basis of conquest and further consolidation, the geopolitical goal was to create a "Kievan principality" embracing the territorial triangle Liublin-Odessa-Chernigov. In this endeavor Vienna anticipated the cooperation of Ukrainian and Polish separatists.

These are more than the musings of an armchair strategist. At the very least, they reveal familiarity with major in-house publications of the Russian General Staff on the nature and scope of Austro-Hungarian military capabili-

18 Bizhevye vedomosti, no. 14252, 15 July 1914 (evening edition), 2-3. 
ties. For example, access to a single two-volume publication, Vooruzhennye sily Avstro-Vengrii (po dannym k 1-mu dekabria $1912 \mathrm{~g}$. [The Armed Forces of Austria-Hungary according to Data up to 1 December 1912], would facilitate assembly of materials on the Austro-Hungarian Army and its troop mobilization system. ${ }^{19}$ But, it would have been impossible from these publications either to illuminate the degree of German support, to identify major Austro-Hungarian axes of advance, or to calculate with any degree of accuracy the balance of Austro-Hungarian troop allocations between Serbia and Russia. However, Solomonov in his first article foresees an initial Austro-Hungarian allocation of at least six (possibly 7) corps against Serbia, an assumption that corresponds with one of Agent No. 25's final transmissions about Vienna's calculations for Fall R, the strategic deployment plan for Galicia in the event of war against Russia. ${ }^{20}$ Similarly, Solomonov assumes German cooperation against Russia, but he does not enumerate the exact number of corps that Germany would send east in the event of European war. Nonetheless, his discussion of separate German incursions from both Silesia and East Prussia would amount to roughly six German corps. This approximation corresponded with Agent 25's notes about German assurances during the Mobilization crisis of late 1912. ${ }^{21}$ None of this information would have been available either from the Russian General Staff's in-house publications or from the mere speculations of informed observers.

19 Glavnoe Upravelnie General'nogo Shtaba, Vooruzhennye sily Avstro-Vengrii (po dannym k 1-mu dekabria 1912 g.), 2 vols. (St. Petersburg: no publisher, 1912).

20 Report, Major General Monkevits, 30 May 1913, Rossiiskii Gosudarstvennyi Voenno-Istoricheskii Arkhiv (hereafter RGVIA), fond [collection] 2000, opis' [inventory] 1, delo [file] 2869, list [folio] 287.

21 Letter, Agent No 25, ca. 26 November 1912, RGVIA, f. 2000, op. 1, d. 2851, 1. 20. 
Almost assuredly, they would have come from the leaked findings of Russian military intelligence.

The same assertion does not hold entirely true for Solomonov's suppositions about the main avenues of advance into the Russian borderlands and beyond. It would have been logical to conclude from contemporary maps that the two more likely avenues from the west into the Russian interior ran north and south of the Pripat Marshes. They constituted an immense north-south geographical barrier that necessitated a bypass at either extreme. What seems unique about Solomonov's treatment is the way that he anticipates the nature of potential enemy approaches over these avenues. One incursion is segmented and phased, while the other is direct, with little ostensible phasing. This level of sophistication suggests general staff-style analysis, if not intelligence-informed input.

Solomonov conveys a picture of Austro-Hungarian capabilities and courses of action that is sufficiently accurate to constitute an informed overview, but not so telling that it might give away sources, means, methods, and the exact extent of Russian intelligence on Austro-Hungarian preparations for possible war. The articles do not give away Russian knowledge of Austro-Hungarian covert mobilization, nor is there any detailed discussion of varying mobilization regimes governed by Fall R. Still, the articles offer more than a passing glimpse of Austro-Hungarian mobilization capacities and military potential.

Substance and timing lobby strongly in favor of an assertion that Solomonov's articles constituted an intelligence-informed attempt to accomplish two objectives. The first was to put Vienna on notice, in effect to say "We know what you're up to." Left unspoken (and technically forbidden by Russian censorship) was the understanding that Russia would undertake appropriate countermeasures. 
A likely second objective was to prepare educated Russian opinion for possible war. Unlike the situation during early 1909 and late 1912, the War Ministry was now actively attempting to seize the domestic high ground in the information struggle. ${ }^{22}$ In light of Sukhomlinov's earlier posturing in the pages of Birzhevye vedomosti, it seems probable that it was the War Minister himself who provided sufficient intelligence-informed insight to flesh out the substance of Solomonov's articles. Finally, the articles demonstrate that the phenomenon of leaking inside information to the press far antedated a practice that in more recent times has become a minor industry in itself.

\section{Galicia: Pre-War Perceptions Versus Wartime Realities}

Formal war declarations ignited minor sparring along national boundaries, but large-scale operations began only upon completion of troop mobilization, transit to concentration, and march-maneuver to contact. Without benefit of extensive aerial and ground reconnaissance, large-scale formations groped for one another to establish and develop contact. Until actual contact afforded additional insight into enemy deployments and order of battle, higher-level commanders per force relied on pre-war intelligence-based assumptions and estimates to identify likely enemy areas of concentration and to discern the direction and scale of enemy main efforts. Lack of serviceable aircraft and a delay in the Austro-Hungarian formal declaration of war precluded timely Russian air and ground reconnaissance to update pre-war assumptions and estimates. Thus, the commander

22 See the contrast in A. V. Ignat'ev, Russko-angliiskie otnosheniia 19081914 gg. (Moscow: Nauka, 1962), 156-57. 
of the Russian Southwest Front initially arrayed his troops against Austria-Hungary on the basis of peacetime intelligence estimates. For all their quality, they would be overtaken by events, and there were lacunae and key miscalculations that nearly led to catastrophic consequences.

On the basis of accurate information that dated to late 1912 and early 1913, Russian intelligence assessments identified two likely Austro-Hungarian axes of advance from Galicia into Russian Poland and beyond. One axis extended north through Liublin to Siedlce, providing the opportunity to link up with advancing German troops from East Prussia. From there, combined operations would unfold in the direction of Brest-Litovsk and then northeast along a main avenue of approach into the Baltic Provinces. A second axis of advance extended from eastern Galicia into Volynia and Podolia to threaten Kiev (and perhaps ultimately, Moscow). ${ }^{23}$ With some variation to obscure genuine estimates and assumptions, these were the same avenues that Solomonov had identified in the pages of Birzhivye vedomosti.

To serve these axes of advance, Russian intelligence assessments, again based on information that dated to late 1912 and early 1913, placed one major set of Austro-Hungarian troop concentrations in the area north and slightly west of L'vov, some 80 kilometers south of the border with Russian Poland. From this concentration two Habsburg armies would push northward through Liublin and Kovel' to link up with Germans troops to the north. Two additional Austro-Hungarian armies would concentrate in the region of Tarnopol-Brody to advance eastward into the region south of the Pripat against important Russian railroad junctions at Rovno-Dubno-Proskurov. ${ }^{24}$

\footnotetext{
23 Intelligence Summary, Lieutenant General Danilov, 1 March 1914, RGVIA, f. 2003, op. 1, d. 1118, 1l. 56-8.
}

24 Ibid., 60, 64-8. 
Necessarily left unwritten in Solomonov's analysis were the dispositions and actions that Russian planners had adopted to exploit their knowledge of Austro-Hungarian deployments and vulnerabilities. Two factors figured heavily in Russian war planning. The first was the changing strategic landscape that opened new possibilities and opportunities over the span between 1910 and 1914 . The second was access to Austro-Hungarian deployment plans that came from Agent No. 25. It was on the basis of these developments that in early 1912 Lieutenant General Mikhail Vasel'evich Alekseev had proposed a major shift in emphasis to identify Austria-Hungary as the primary initial objective in Russian war planning. With more than 20 Russian field army corps available, he would assign only six or seven to engage in a holding action against German forces in East Prussia. The remainder he would send against Austria-Hungary. They would come from two directions. One large army (later deployed as two field armies) was to advance westward into Galicia from the Rovno-Dubno-Proskurov complex to serve as an anvil. Two additional armies were to advance from Liublin-Khom-Kovel' rail corridor along the southern border of Russian Poland to attack southeast. They were to serve as the hammer, with the object of crushing main Austro-Hungarian dispositions in a gigantic modern reincarnation of the classical Greek battle of single-envelopment at Leuctra in $371 \mathrm{BC} .{ }^{25}$

In turn, two sets of changes affected the way that these plans would actually unfold in August 1914. One included altered priorities stemming from Franco-Russian alliance considerations that called for engagement with substantial

25 Bruce W. Menning, "War Planning and Initial Operations in the Russian Context," in Richard F. Hamilton and Holger H. Herwig, eds., War Planning 1914 (Cambridge: Cambridge University Press, 2010), 115-17. 
Russian forces (800,000 troops) against Germany by $\mathrm{M}+15$ (Mobilization Day plus 15 days). To accommodate assurances to the French, Russian war planners reduced Alekseev's original troop allocations against Austria-Hungary and expanded the commitment against Germany. This decision left Alekseev's original design neither fish nor fowl: As amended, it allocated too little against Germany, and it failed to provide the necessary overwhelming numbers against Austria-Hungary. ${ }^{26}$ Although General Alekseev's plan of 1912 was not without its faults, it had promised perhaps the highest degree of initial success of any of the war plans of the Great Powers. As revised, it now promised only indecision.

The second set of changes was beyond Russian control. During 1913 and early 1914, Franz Conrad von Hötzendorf, the Chief of the Austro-Hungarian General Staff, introduced substantial alterations into his anticipated wartime deployments for initial operations from Galicia. For reasons that remain unclear-but in part likely a corrective measure against the successes of Russian espionage-he moved his initial army grouping opposite the southern reaches of Russian Poland farther to the west and rear, while reinforcing the grouping's left-wing formations. ${ }^{27}$ Having lost Agent No. 25 and various agent networks in Austria-Hungary early in 1913, the Russians were ignorant of this development.

Unknown to the Russians, these changes seriously undermined the viability of their war plan against Aus-

26 Ibid., 120-26. See also, Graydon A. Tunstall, Jr., Planning for War against Russia and Serbia: Austro-Hungarian and German Military Strategies, 1871-1914 (Boulder, Colorado and Highland Lakes, New Jersey: Social Science Monographs and Atlantic Research and Publications, 1993), 96.

27 N. N. Golovin, Iz istorii kampanii 1914 goda na russkom fronte. Galitsiiskaia bitva (Paris: Izdatel'stvo glavnogo pravleniia zarubezhnogo Soiuza voennykh invalidov, 1930), 53-5. 
tria-Hungary. Opposite Galicia, Russian Mobilization Plan 19A called for the concentration of two field armies (the Fourth and Fifth) along the Liublin-Kholm-Kovel' rail corridor. Two additional armies (the Third and Eighth) would concentrate to the east, and together the two army groupings would constitute the prongs of a gigantic pincer intended to entrap the Austro-Hungarians in a gigantic double envelopment operation northwest of L'vov. ${ }^{28}$ Time, as always, was a complicating factor, because the Austro-Hungarian Army possessed a six-seven day advantage over the Russian army in speed of mobilization and concentration for initial operations.

With Russian planners oblivious of the unknown, time remained the known factor that weighed heavily on calculations for initial deployments. And, it was in the realm of time translated into speed of troop mobilization that prewar perceptions based on intelligence proved only partially correct. For example, Intelligence estimates from St. Petersburg on 18/31 July indicated that the three Austro-Hungarian corps (I, X, XI) resident in Galicia had been undergoing mobilization as early as $15 / 28$ and 16/29 July. However, a supplementary estimate for the period 26 July/8 August through 3/16 August indicated that Austro-Hungarian troop mobilization was proceeding more slowly than expected, perhaps because of conflicting priorities over troop allocations to various fronts. The same estimate warned, "so far, there is insufficient data to gauge what kind of changes the Austrians have introduced into their plan for strategic deployment in Galicia." ${ }^{29}$ Without additional detail, these assertions proved insufficient to challenge pre-war

28 Menning, "War Planning," 125, 135-37

29 Intelligence Estimate, Colonel Rostkovskii, 26 July through $3 \mathrm{Au}-$ gust [1914]," RGVIA, f. 2003, op. 1, d. 779, 1. 115 obratnaia [obverse]. 
assumptions and conclusions. Accordingly, the prevailing wisdom was that Vienna would have completed its troop mobilization by 26 July/8 August. ${ }^{30}$ This date corresponded with the eighth day of a Russian troop mobilization that would extend another 13 days for completion of transit by the initial echelon of front-line troops. The time differential that translated into lopsided troop readiness rates for initial operations remained an issue of grave concern for Russian commanders and their staffs. Even before Lieutenant General Alekseev, Chief of Staff for Southwest Front, had departed Kiev for his wartime headquarters in the field, he was already pondering the negative calculus and anticipating the possibility of drawing the Front's initial dispositions away from the vulnerable rail corridor. ${ }^{31}$

Events soon overtook vague premonitions and Alekseev's apprehensions. On 9/22 August, General Nicholas Nikolaevich Ianushkevich, Chief of Staff at field headquarters of the Supreme Commander, belatedly telegraphed a warning about changed Austro-Hungarian dispositions to General Nicholas Iudovich Ivanov, Commander of Southwest Front. The source for the warning remains unclear, but subsequent correspondence indicates information from the Russian military attaché in Rome. ${ }^{32}$ Ianushkevich warned,

30 Intelligence Estimate, Major General Pustovoitenko, 21-24 July 1914, RGVIA, f. 2067, op. 1, d. 2317, 1. 3. The enlargement of the already substantial mobilization gap between Russia and Austria-Hungary is explained by the fact that Russian intelligence specialists calculated the onset of the latter's mobilization to the time (15/28 July) of the declaration of partial mobilization against Serbia, while Russia's declaration for general mobilization came only on 17/30 July, with actual mobilization beginning only on the following day.

31 Memorandum, Lieutenant General Alekseev to Commander-in-Chief, Southwest Front, 24 July 1914, RGVIA, f. 2067, op. 1, d. 125, 1. 9ob.

32 Intelligence Estimate, Major General Monkevits, 12 August 1914, RGVIA, f. 2003, op. 1, d. 779, 1. 121ob. 
"It is possible in the interests of caution that they [the Austro-Hungarians] have concentrated a large part of their forces west of where we have usually calculated, for example, in the region Kraków-Przemyśl. Therefore, Ianushkevich held that launching the Russian Fourth and Fifth Armies into an offensive against the front Lvov-Rzeszów "seems no longer to correspond with the situation." These circumstances aside, the Supreme Commander, Grand Duke Nicholas Nikolaevich, promised no additional help. Instead, the Grand Duke via Ianushkevich merely asserted that he "expected from the armies entrusted to you [General Ivanov)], especially the Third and Eighth, rapid, energetic, and relentless actions." ${ }^{33}$

This message came almost too late, but it did clarify the situation that Ivanov and Alekseev were about to confront. With the Third and Eighth Armies still far to the east, on 10/23 August elements of Ivanov's Fourth and Fifth Armies collided just south and west of Liublin in a series of meeting engagements with two reinforced Austro-Hungarian shock armies. The Russians recoiled under heavy losses, fighting with their backs to the Liublin-Kholm-Kovel' rail corridor. Acting as Ivanov's chief of operations, Alekseev parried enemy blows by reorienting the Fifth Army's axis of advance to bring it into closer cooperation with the Fourth. Then, even as the badly-mauled Fourth Army was falling back on its railhead at Liublin, the Grand Duke relented to grant reinforcements. Only timely reinforcement-including the arrival of subsequent troop mobilization echelons-and the advancing Russian Third and Eighth Armies from the east finally relieved the situation. However, it would be a closerun affair before Russian Southwest Front emerged victorious from its initial border battles to advance into Galicia.

33 Ianushkevich to Ivanov, 9 August 1914, RGVIA, f. 2067, op. 1, d. 126, 11. 17-18. 
Conclusion

These three vignettes offer additional insight into the uses and limitations of Russian military intelligence during the July Crisis of 1914 and shortly thereafter. The conversation between Emperor Nicholas II and Colonel Pestrzhetskii occurred before Vienna had embarked on the troop mobilization measures that Russian military intelligence specialists found so alarming. Thus, rather than prompting a sense of resolve, subsequent intelligence assessments may have simply reinforced an a priori sense of commitment to assist Serbia. Although pro-Serbian sentiment no doubt figured in various calculations, Russian interests perhaps weighed even more heavily in the Emperor's sense of early-on resolve. Mikhail Nikolaevich Girs, at the time Russian Ambassador to Constantinople, poignantly summarized much of prevailing official opinion on the geopolitical considerations at stake. On 14/27 July, he had written to Foreign Minister Sergei Dmitrievich Sazonov: "There should be no doubt about what is self-evident-Serbia will in the end be dismembered by its powerful neighbor." In consequence, the logical result would be "the complete ruination of the Balkan political balance ... and the final drawing of the Turks into the Triple Alliance, thus rendering them our enemies." ${ }^{34}$ In sum, there was good reason beyond mere sentiment for the Russian Emperor's support of Serbia, the intelligence perspective notwithstanding. Meanwhile, as the July Crisis cascaded into the following full week, military intelligence would nevertheless play a vital role in assessing warnings and indicators of possible war. There would also be room via the press to make intelligence the

34 Girs to Sazonov, 14/27 July 1914, in Tsarsksaia Rossiia $v$ mirovoi voine (Leningrad: Gosudarstvennoe izdatel'stvo, 1925), 5. 
handmaiden of diplomacy and information-sharing with the broader reading public. K. M. Solomonov's articles provide eloquent testimony to this fact. However, intelligence also had its limitations, especially under the changing circumstances of 1913 and early 1914, when Russia lost significant collection assets in Austria-Hungary. Without their timely input during the months prior to conflict, Russian armies would undertake initial operations half-blind, with baleful results. Indeed, Colonel Pestrzhetskii's $12^{\text {th }}$ Astrakhan Grenadiers would lose nearly half their complement while holding the line against near-overwhelming odds at Zamość, just southeast of Liublin. Historian and general staff officer Alexander Konstantinovich Kolenkovskii subsequently noted the difficulty of bridging the gap between pre-war intelligence and intelligence in the field at the outset of operations..$^{35}$ There is perhaps no better illustration of this challenge than the fate of the Russian Fourth and Fifth Armies in August 1914.

35 A. K. Kolenkovskii, Manevrennyi period pervoi mirovoi imperialisticheskoi voiny 1914 g. (Moscow: Gosudarstvennoe Voennoe Izdatel'stvo, 1940), 104-05. 